\title{
Simvastatin nanoparticles attenuated intestinal ischemia/reperfusion injury by downregulating BMP4/COX-2 pathway in rats
}

This article was published in the following Dove Press journal:

International Journal of Nanomedicine

29 March 2017

Number of times this article has been viewed

\author{
Fei Tong' \\ Bo Dong' \\ Rongkui Chai \\ Ke Tong ${ }^{2,3}$ \\ Yini Wang ${ }^{4}$ \\ Shipiao Chen' \\ Xinmei Zhou' \\ Daojun Liu ${ }^{5}$ \\ 'Department of Pathology and \\ Pathophysiology, Provincial Key \\ Discipline of Pharmacology, Jiaxing \\ University Medical College, Jiaxing, \\ Zhejiang, ${ }^{2}$ College of Life Science \\ and Engineering, ${ }^{3}$ State Defense Key \\ Laboratory of Fundamental Science \\ on Nuclear Wastes and Environment, \\ Southwest University of Science \\ and Technology, Mianyang, Sichuan, \\ ${ }^{4}$ Department of Nursing, Zhejiang \\ Rongjun Hospital, The Third People's \\ Hospital of Jiaxing, Jiaxing, Zhejiang, \\ ${ }^{5}$ Department of Pharmacochemistry, \\ Shantou University Medical College, \\ Shantou, Guangdong, People's \\ Republic of China
}

\begin{abstract}
The purpose of the research was to explore the therapeutic action of simvastatin-loaded poly(ethylene glycol)- $b$-poly (gamma-benzyl L-glutamate) (PEG- $b$-PBLG ${ }_{50}$ ) on intestinal ischemia/reperfusion injury (II/RI) through downregulating bone morphogenetic protein 4 (BMP4)/cyclooxygenase-2 (COX-2) pathway as compared to free simvastatin (Sim). Sprague Dawley rats were preconditioned with $20 \mathrm{mg} / \mathrm{kg}$ Sim or simvastatin/PEG- $b-$ PBLG $_{50}$ $(\mathrm{Sim} / \mathrm{P})$ compounds, and then subjected to $45 \mathrm{~min}$ of ischemia and $1 \mathrm{~h}$ of reperfusion. The blood and small intestines were collected, serum levels of interleukin-4 (IL-4), interleukin-6 (IL-6), interleukin-10 (IL-10), tumor necrosis factor- $\alpha$, and nitric oxide (NO) were checked, and the dry/wet intestine ratios, superoxide dismutase activity, myeloperoxidase content, reactive oxygen species, endothelial nitric oxide synthase, protein $47 \mathrm{kDa}$ phagocyte oxidase (p47phox), BMP4, COX-2, and p38 mitogen-activated protein kinase (p38MAPK) expressions were measured in intestinal tissues. Both Sim and Sim/P pretreatment reduced intestinal oxidative damnification, restricted inflammatory harm, and downregulated the BMP4 and COX-2 expressions as compared to II/RI groups, while Sim/P remarkably improved this effect.
\end{abstract}

Keywords: PEG- $b$-PBLG ${ }_{50}$, II/RI, simvastatin, BMP4, COX-2

\section{Introduction}

Intestinal ischemia/reperfusion injury (II/RI) is a major pathophysiological phenomenon and a potentially life-threatening problem in clinical medicine. ${ }^{1,2}$ The mortality rates from II/RI are very high and reach more than $60 \%$ and it often requires clinical operation to cut off the necrotic intestinal segment. ${ }^{3,4}$ It causes the tissue injury through inadequate blood and oxygen supply relative to cellular energy stores exhaustion, tissue metabolic disorder, and toxic metabolites accumulation in intestinal ischemia phase and leads to reactive oxygen species (ROS), inflammatory factors, calcium overload, and so on, mediating the further damage of intestine in reperfusion phase. ${ }^{5}$ It is well known that oxygen supply reestablishment results in ROS production, causing lipid oxidation reaction in cell membranes, ${ }^{6}$ and blood supply reestablishment leads to production of a lot of inflammatory factors to aggravate tissue injury and intestinal barrier dysfunction, and toxic metabolite products enter the systemic blood circulation and threaten life. ${ }^{7}$

ROS is engendered on intestinal ischemia/reperfusion (I/R), and is one of the major reasons of intestinal damage. ${ }^{8}$ Previous studies have showed that nicotinamide adenine dinucleotide phosphate (NADPH) oxidase is the key enzyme that is involved in ROS production. ${ }^{9} \mathrm{NADPH}$ oxidase is composed of at least five protein components 
and three cytosolic components (including p47phox). ${ }^{10}$ p47phox is the subunit mainly responsible for transporting the cytosolic complex from the cytosol to the membrane in oxidase activation and impels ROS production. ${ }^{10}$ Many exogenous antioxidants (including superoxide dismutase [SOD]) aimed to reduce ROS damage have been studied in the treatment of I/R-induced intestinal injury. ${ }^{11}$ More and more evidence has demonstrated that stimulation of endogenous antioxidant systems may be an important tactic for achieving intestinal protection on I/R injury. ${ }^{11}$

The disorder of proinflammatory and anti-inflammatory factors boosts II/RI. ${ }^{1}$ Proinflammatory factors including interleukin-6 (IL-6) and tumor necrosis factor (TNF- $\alpha$ ) generated largely, and anti-inflammatory factors including interleukin-4 (IL-4) and interleukin-10 (IL-10) engendering insufficiently via damaged intestines and blood have been involved as the chief contributor of II/RI. ${ }^{12,13}$

Bone morphogenetic protein 4 (BMP4) is one of the BMP families (including BMP2-BMP9).${ }^{14}$ Previous studies have affirmed that BMP4 has a role with BMP receptors involving type I and type $\mathrm{II}^{15}$ and then adjusts physiopathologic process of bodies. ${ }^{16-18}$ Some documents have shown that BMP4 exacerbates exaggeratin cardiac I/R injury. ${ }^{19}$ In addition, BMP4 is a proinflammatory gene that induces endothelium dysfunction, mediating abnormal expression of endothelial nitric oxide synthase (eNOS) and leads to impairment of vascular relaxation, ${ }^{20}$ and that activates NADPH oxidase to induce ROS production and then improves the expression of cyclooxygenase-2 (COX-2) through p38 mitogen-activated protein kinase (p38MAPK). ${ }^{21} \mathrm{COX}-2$ promotes vasopermeability and aggravates tissues' damage. ${ }^{21}$

Many documents have attested that simvastatin (Sim) can protect the small intestine against (I/R) damnification. ${ }^{22-24}$ In the present study, we try to explore the protective effect of Sim on II/RI. As is well known, the in vivo solubility of Sim is very low and circulation time is very short. ${ }^{25-27}$ Here, a poly(ethylene glycol)- $b$-poly(gamma-benzyl L-glutamate) (PEG- $b-\mathrm{PBLG}_{50}$; P) block multipolymer (framework depicted in Figure 1) as a latent Sim nanoparticle is reported. The block multipolymer is synthesized through the ring-opening polymerization of BLG- $N$-carboxyanhydride (NCA) with PEG-NH $\mathrm{N}_{2}$ as the macroinitiator. The P and Sim integrate into a compound through hydrophobic functions. The encapsulated Sim shows stable release, which can promote the research on the protective action of Sim. Sim loading and in vitro release are confirmed. In vivo research is conducted through the hypodermic injection of the Sim/P compound to II/RI in rats, followed by the determination of serum IL-4, IL-6, IL-10, TNF- $\alpha$, and nitric oxide (NO),

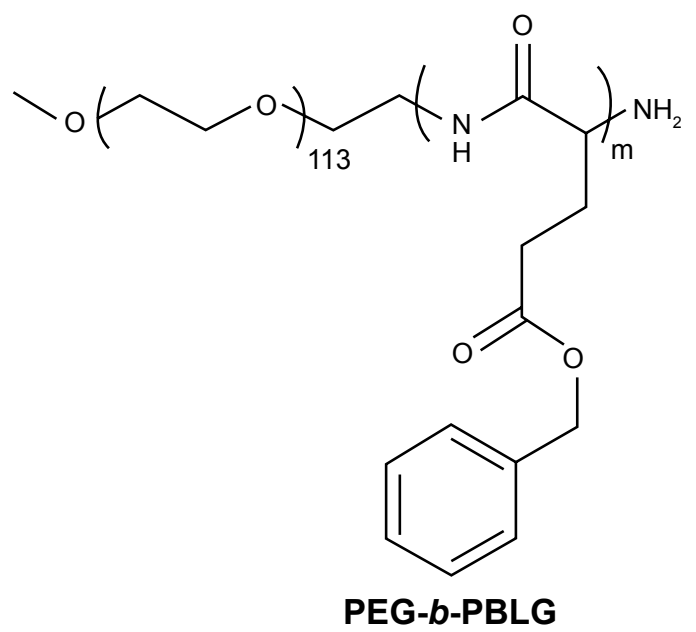

Figure I The structure of PEG-b-PBLG.

Note: " $m$ " represents the degree of polymerization.

Abbreviation: PEG-b-PBLG, poly(ethylene glycol)-block poly(gamma-benzyl L-glutamate).

measurements of SOD activity and methane dicarboxylic aldehyde (MDA) level in small intestinal tissues, and finally the ROS, eNOS, protein $47 \mathrm{kDa}$ phagocyte oxidase (p47phox), BMP4, COX-2, and p38MAPK expressions in small intestinal tissues.

\section{Materials and methods \\ Material}

PEG-NH ${ }_{2}$ (molecular weight, $5 \mathrm{kDa}$ ), dimethyl formamide (DMF), and BLG were bought from Aladdin (Shanghai, China); regenerative fiber dialysis bag (molecular weight cut off [MWCO], $3.5 \mathrm{kDa}, 7 \mathrm{kDa}$ ) was bought from Union Cardibide Company (Danbury, CT, USA); simvastatin was bought from Shangyu Hangzhou Jing Xin Pharmaceutical Co., Ltd; Hela cells were bought from Shanghai Forte Cheng Biological Technology Co., Ltd; other reagents were bought from Sigma.

\section{Methods}

\section{Synthesis of PEG-b-PBLG 50}

PEG- $b$-PBLG50 was synthesized by following way: The ring-opening polymerization of BLG-N-carboxyanhydride with PEG-NH $\mathrm{N}_{2}$ as the macroinitiator obtained PEG- $b$-PBLG, as described in Figure 2. BLG-NCA was synthesized and characterized by a previously published method. ${ }^{28}$ The right amount of PEG-NH $\mathrm{N}_{2}$ in $10 \mathrm{~mL}$ of DMF was mixed with a quantity of BLG-NCA/DMF fluid $(0.1 \mathrm{~g} / \mathrm{mL})$ by vacuumization and nitrogen protection. The corresponsive compounds were stirred at $40^{\circ} \mathrm{C}$ for 3 days and dialyzed for 3 days using dialysis tubing (MWCO, $7 \mathrm{kDa}$ ). The PEG- $b$-PBLG polymers were gained by freeze drying, the degree of polymerization of PBLG was 50, and they were characterized by ${ }^{1} \mathrm{H}$-nuclear 
A
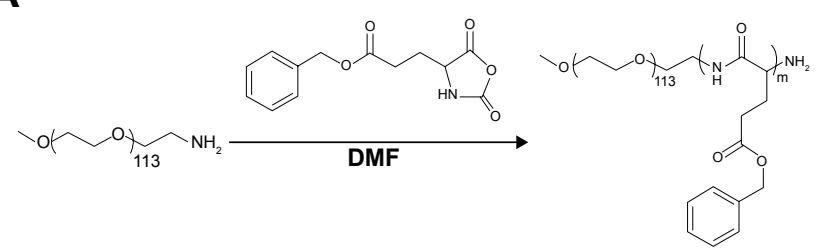

PEG-b-PBLG
B

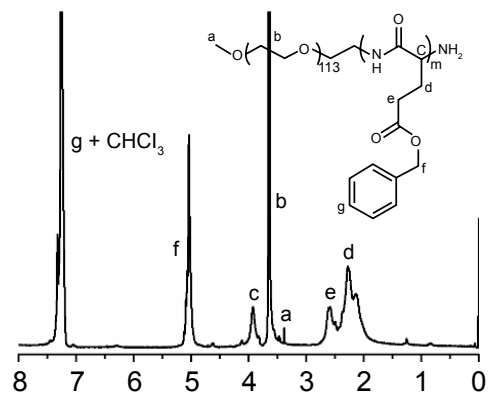

D

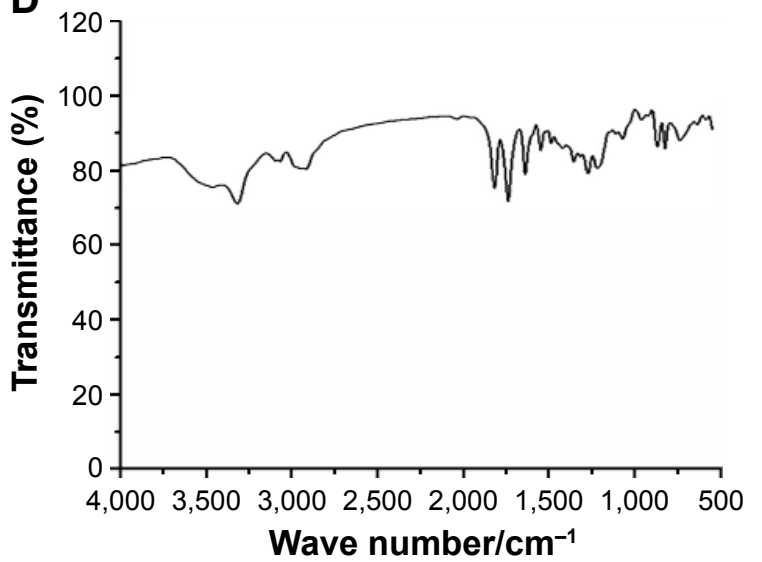

Figure 2 (A) Synthesis of of PEG-b-PBLG ${ }_{50}$; (B) 'H NMR spectra of PEG-b-PBLG ${ }_{50}$ and its intermediates; (C) Gel permeation chromatograms of PEG-b-PBLG ${ }_{50}$; (D) Fourier transform infrared spectroscopy of PEG-b-PBLG ${ }_{50}$.

Abbreviations: DMF, N-dimethylformamide; 'H NMR, 'H-nuclear magnetic resonance; PEG-b-PBLG ${ }_{50}$, poly(ethylene glycol)-b-poly(gamma-benzyl L-glutamate); PEG-NH, poly(ethylene glycol) amine.

magnetic resonance, gel permeation chromatogram, and Fourier transform infrared spectroscopy.

\section{Cytotoxicity evaluation of PEG-b-PBLG ${ }_{50}$}

The detailed method for the cytotoxicity evaluation of block copolymer PEG- $b$-PBLG $\mathrm{G}_{50}$ is referred to the technology and method specified in our previous article. ${ }^{29}$

\section{Encapsulation of simvastatin through PEG-b-PBLG ${ }_{50}$} To assess the loading of simvastatin by PEG- $b-\mathrm{PBLG}_{50}$, a certain amount of simvastatin $(5 \mathrm{mg} / \mathrm{mL})$ in phosphate buffered solution (PBS) $(\mathrm{pH}=7.2,0.01 \mathrm{mmol} / \mathrm{L}$; including $2 \%$ dimethyl sulfoxide) was mixed with PEG- $b-$ PBLG $_{50}$ in a PB solution. And then the mixed solutions were transferred to a dialysis bag (MWCO, $7 \mathrm{kDa}$ ) and dialyzed. When the sunk polymer in the test was wholly removed, the polymer-loaded simvastatin was measured through high-performance liquid chromatography (HPLC) and transmission electron microscopy (TEM).

\section{In vitro release of simvastatin from PEG-b-PBLG ${ }_{50}$} Simvastatin releases from the PEG- $b-\mathrm{PBLG}_{50}$ were detected by dialysis (MWCO, $7 \mathrm{kDa}$ ) at room temperature with $5 \mathrm{~mL}$ of simvastatin/PEG- $b$-PBLG s0 $_{50}$ compound against $60 \mathrm{~mL}$ of $0.02 \mathrm{~mol} / \mathrm{L} \mathrm{PB}$ (pH 7.4). At 0.02-, 0.04-, 0.08-, 0.17-, 0.33-,
0.42-, 0.5-, 0.67-, 0.75-, 1-, 1.5-, 1.67-, 1.75-, 2-, 3-, and 4-day time interval, a certain amount of release mediums were retrieved and supplemented with a proper amount of fresh release mediums. The quantity of released simvastatin remaining in the dialysis bag was measured through HPLC. The free simvastatin releases in the absence of polymeric compound were also executed as a control.

\section{Blood simvastatin concentration evaluation}

The Sprague Dawley (SD) rats were administrated a dose of $20 \mathrm{mg} / \mathrm{kg}$ simvastatin (Sim) or simvastatin/PEG- $b-\mathrm{PBLG}_{50}$ (Sim/P) by abdominal subcutaneous injection. Blood $(0.2 \mathrm{~mL})$ was extracted to put into heparinized tubes at specified time intervals. Blood was separated immediately by centrifugation $\left(12,000 \times g\right.$ for $15 \mathrm{~min}$ at $\left.4^{\circ} \mathrm{C}\right)$ and stored under $-80^{\circ} \mathrm{C}$ for the following analyses. The concentration of $\mathrm{Sim}$ and $\mathrm{Sim} / \mathrm{P}$ in rat blood was measured by liquid chromatography tandem mass spectrometry following the previous methods. ${ }^{30}$

\section{The distribution of simvastatin/polymer compound} in $S D$ rats

The SD rats were administrated a dose of $20 \mathrm{mg} / \mathrm{kg} \mathrm{Sim}$ or $\mathrm{Sim} / \mathrm{P}$ by abdominal subcutaneous injection. The different tis- 
sues were extracted and put into test tubes, where the miscible liquids containing $0.2 \mathrm{~mL} 60 \%$ perchloric acid and $0.2 \mathrm{~mL}$ $30 \%$ hydrogen peroxide were added. The samples were put into an $80^{\circ} \mathrm{C}$ water bath for $40-60 \mathrm{~min}$ and then the color of the samples became faint yellow. $0.2 \mathrm{~mL}$ of the tissues liquids were extracted to add $1 \mathrm{~mL}$ of scintillation solution and $3 \mathrm{~mL}$ of absolute ethyl alcohol, then the radioactivity of different tissues were checked by TRI-CARB2900 TR liquid scintillation counter (PACKARB) following previous methods. ${ }^{31}$

\section{Animal and surgical procedures of I/R}

SD rats (180-220 g) were accommodated by the Animal Research Center of Jiaxing University Medical College, Jiaxing, People's Republic of China. All the procedures and care administered to the animals had been approved by the Institutional Ethics Committee of Jiaxing University Medical College. The investigation conformed to the guide for the care and use of laboratory animals published by the US National Institutes of Health (NIH Publication updated in 2011). In the research, $40 \mathrm{SD}$ rats were assigned to four groups (each group including 10 rats): 1) Sham group; 2) I/R group: SD rats were anesthetized with $1 \%$ pentobarbital sodium $(50 \mathrm{mg} / \mathrm{kg})$ through intraperitoneal injection. The abdomina were opened and the arteriae mesenterica superior were separated to be clamped for $45 \mathrm{~min}$ by a small vessel clip, followed by $1 \mathrm{~h}$ of reperfusion; 3 ) simvastatin ( $\mathrm{Sim}$ ) group: Sim was administrated once a day $(20 \mathrm{mg} / \mathrm{kg})$ through abdominal subcutaneous injection, for 8 days prior to the I/R procedures; 4) simvastatin/ PEG- $b-$ PBLG $_{50}$ (Sim/P) group: Sim/P was administrated once every 4 days $(20 \mathrm{mg} / \mathrm{kg})$ through abdominal subcutaneous injection, for 8 days prior to the I/R procedures. The blood was collected from the abdominal aorta and centrifuged under $3,600 \times g$ for $20 \mathrm{~min}$ to gain the sera. A segment of small intestine of SD rats was removed to weigh the wet intestine and it was baked for $48 \mathrm{~h}$ under $80^{\circ} \mathrm{C}$ to weigh the dry intestine. A segment of small intestine was cut off right away and stored at $-80^{\circ} \mathrm{C}$ until analysis.

\section{SOD activity and MDA content evaluation}

SOD activity and MDA content of intestinal tissues were checked using the previous methods. ${ }^{32}$ The intestines were collected after reperfusion for $1 \mathrm{~h}$ and the blood was purged drastically, homogenized (100 mg), and centrifuged at $3,600 \times g$ for $20 \mathrm{~min}$ to gain the liquid supernatant. SOD activity and MDA level were checked through xanthine oxidase and thiobarbituric acid method. ${ }^{30}$ The absorbances were checked at 550 and $532 \mathrm{~nm}$, respectively. Lipid peroxide contents are shown by "U" of SOD/mg pro and "nmol" of $\mathrm{MDA} / \mathrm{mg}$ pro in tissues.

\section{Evaluation of serum NO level}

The methods have been described previously. ${ }^{33}$ The blood was collected after reperfusion for $1 \mathrm{~h}$ and centrifuged at $3,600 \times g$ for $20 \mathrm{~min}$ to gain the liquid supernatant. The $\mathrm{NO}_{2}{ }^{-} / \mathrm{NO}_{3}{ }^{-}$content was measured by nitrate reductase and absorption photometry. The absorbances were checked at $550 \mathrm{~nm}$. The content of $\mathrm{NO}_{2}{ }^{-} / \mathrm{NO}_{3}^{-}$is shown in " $\mu$ mol" of $\mathrm{NO}_{2}{ }^{-} / \mathrm{NO}_{3}{ }^{-} / \mathrm{L}$ serum.

\section{Measurement of serum IL-4, IL-6, IL- I0, and TNF- $\alpha$ content}

The method was depicted mainly through previous reports. ${ }^{12,13}$ The sampling process was the same as above. The IL-4, IL-6, IL-10, and TNF- $\alpha$ contents were measured by double anti-sandwich ABC-ELISA method. The absorbances were checked at 450 and $492 \mathrm{~nm}$, respectively. The levels of IL-4, IL-6, IL-10, and TNF- $\alpha$ were expressed in "ng" of IL-4, IL-6, IL-10, and TNF- $\alpha / \mathrm{L}$ serum.

\section{Evaluation of ROS}

Previous methods have been referred to here. ${ }^{34-37}$ After $1 \mathrm{~h}$ of reperfusion, $\mathrm{SD}$ rats were anesthetized with $1 \%$ pentobarbital sodium $(50 \mathrm{mg} / \mathrm{kg})$, and CM-H $\mathrm{H}_{2} \mathrm{DCFDA}(100 \mu \mathrm{g})$ was injected into the intestinal circulation. After $\mathrm{CM}-\mathrm{H}_{2} \mathrm{DCFDA}$ injection, the small intestine was harvested for 45 min and dipped in $4 \%$ paraformaldehyde for about $24 \mathrm{~h}$. After treatment with $20 \%$ sucrose for about $12 \mathrm{~h}$, the small intestine was immediately frozen in liquid nitrogen. Cryostat sections were cut at $-20^{\circ} \mathrm{C}$ and the sections were placed on Star-Frost adhesive slides and air-dried for about $3 \mathrm{~min}$. Parts were washed in PBS and stained with DAPI for fluorescence microscopy analysis in ROS qualitative evaluation. ROS quantitative evaluation in isolated mitochondria was performed using the amplex red $\mathrm{H}_{2} \mathrm{O}_{2}$ /peroxidase assay kit using a spectrofluorometer and emission wavelengths of 544 and $590 \mathrm{~nm}$, respectively.

\section{Western blot analysis}

Previous methods have been referred to here..$^{21,38-40}$ Briefly, small intestinal tissues were homogenized in protein lysate buffer. The homogenate was resolved on polyacrylamide sodium dodecyl sulfate gels, and electrophoretically transferred to polyvinylidene difluoride membranes. The membrane was blocked with $3 \%$ bovine serum albumin, and incubated with primary antibodies (Abs) against active eNOS, p47phox, p38MAPK, BMP4, COX-2, and subsequently with alkaline phosphatase-conjugated secondary Abs. It was developed via 5-b-romo-4-chloro-3-indolyl phosphate/nitroblue tetrazolium. Blot was stained through anti- $\beta$-actin $\mathrm{Ab}$, and the content of protein was normalized with respect to $\beta$-actin and density. 


\section{Immunohistochemical assessment}

Previous methods have been referred to here. ${ }^{41-43}$ Sections with a thickness of $5 \mu \mathrm{m}$ were obtained from the small intestine parts and mounted on poly-L-lysine-coated slides. The parts were immersed in $0.3 \% \mathrm{H}_{2} \mathrm{O}_{2}$ for $20 \mathrm{~min}$ and washed with PBS. The parts were then incubated in rabbit anti-COX-2, anti-BMP4, and anti-p38MAPK polyclonal antiserum (Abcam, UK) for $1 \mathrm{~h}$ (1:100 dilution). After the primary incubation and three rinses in PBS, parts were incubated in biotinylated goat anti-rabbit IgG (Invitrogen, CA, USA) for 15 min (1:2,000 dilution). Following the incubation in substrate chromagen solution for $15 \mathrm{~min}$, all parts were washed in PBS and distilled water, mounted in glycerol, and checked later under the microscope. The small intestinal parts stained positively for COX-2, BMP4, and $\mathrm{p} 38 \mathrm{MAPK}$ were evaluated and compared among groups.

\section{Statistical analysis}

All experiments were repeated in triplicate. All the data were depicted as mean values \pm standard deviation. An analysis of variance test and a Student's $t$-test usually assessed statistical significance. A value of $<0.01(P<0.01)$ was regarded as statistically significant.

\section{Results}

\section{Synthesis and characterization of PEG- $b-\mathrm{PBLG}_{50}$}

The PEG- $b$-PBLG was made up of a PEG block and aPBLG (Figure 1). In the current research, the molecular weight of PEG block was $5 \mathrm{kDa}$, and the degree of polymerization of the PBLG was 50. The synthesis was accomplished in a step order as depicted in Figure 2A. The ${ }^{1} \mathrm{H}$ NMR spectra of PEG- $b-$ PBLG $_{50}$ is depicted in Figure 2B, and the characteristic proton peaks of both PEG and PBLG block were in existence, corroborating that the synthesis proceeded in a controlled way and was successful. The gel permeation chromatograms (GPCs) of PEG- $b$-PBLG are depicted in Figure 3 and the GPCs showed a sharp unimodal GPC peak, and the molecular weight of the termination product PEG- $b-\mathrm{PBLG}_{50}$
A
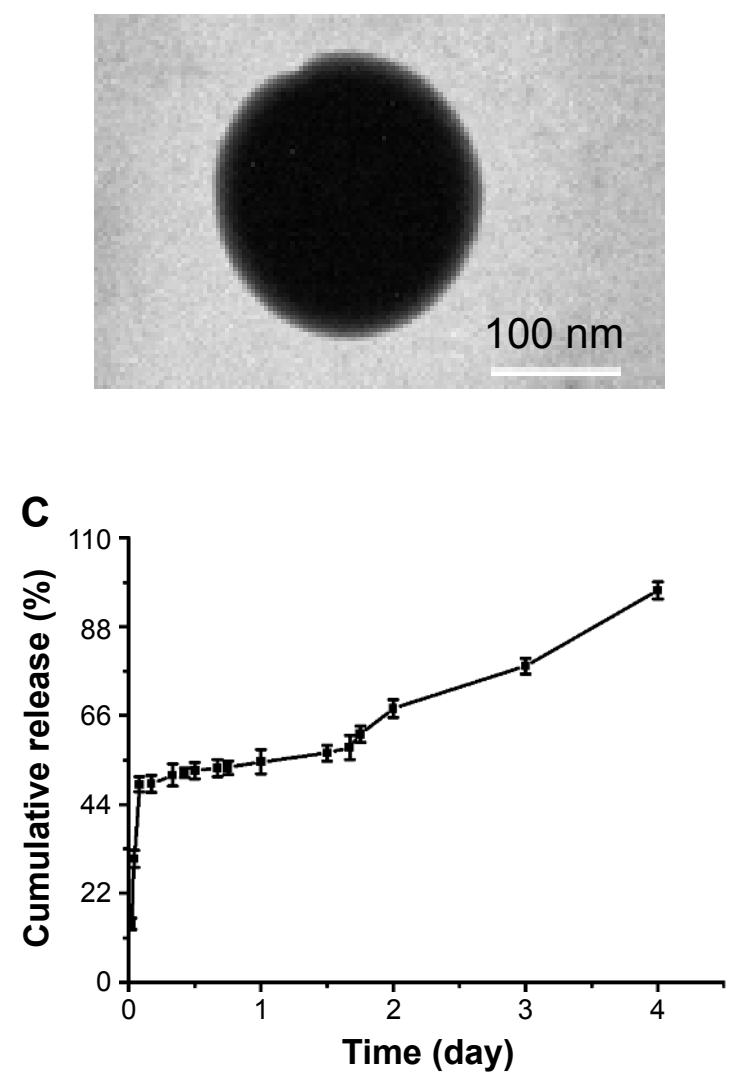

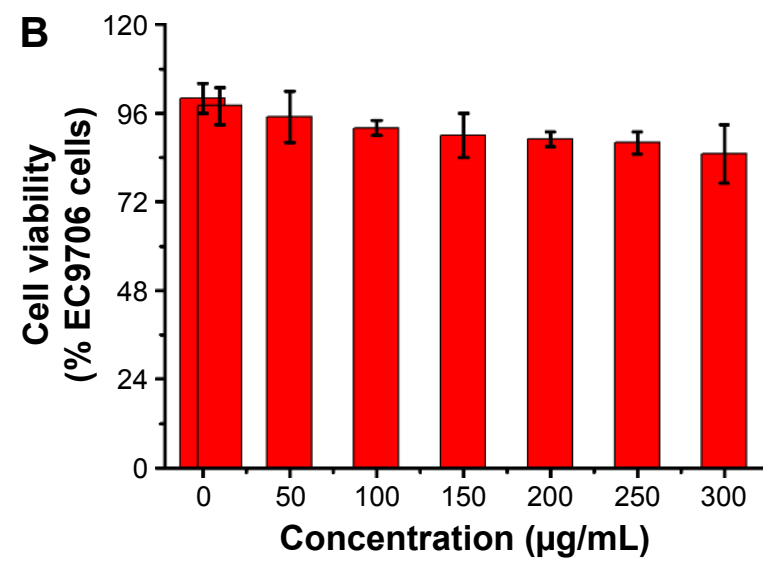

D

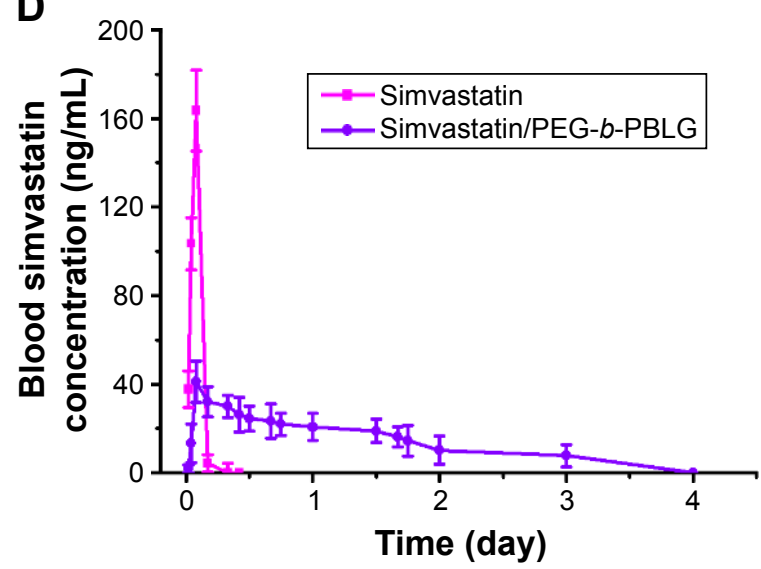

Figure 3 Characterization of PEG-b-PBLG ${ }_{50}$ and simvastatin/PEG-b-PBLG ${ }_{50}$ complexes.

Notes: (A) TEM image of simvastatin/PEG-b-PBLG ${ }_{50}$ complexes; (B) Cellular viability of EC9706 cells cultured with different concentrations of PEG-b-PBLG ${ }_{50}$ and results expressed as mean \pm standard deviation; (C) Cumulative releasing profile of simvastatin from simvastatin/PEG-b-PBLG ${ }_{50}$ complexes and results expressed as mean \pm standard deviation. (D) Blood simvastatin concentration of simvastatin and simvastatin/PEG-b-PBLG ${ }_{50}$ complexes in rats and results expressed as mean \pm standard deviation. Abbreviations: PEG-b-PBLG ${ }_{50}$, poly(ethylene glycol)-b-poly(gamma-benzyl L-glutamate); TEM, transmission electron microscopy. 
gained from the GPC detection is listed in Table 1. The FT-IR of PEG- $b-$ PBLG $_{50}$ is depicted in Figure $3 \mathrm{D}$ and the FT-IR showed that the absorption peaks at 1,734 and $1,167 \mathrm{~cm}^{-1}$ were the ester linkage of PEG- $b-\mathrm{PBLG}_{50}$ and the characteristic peaks at 1,652 and 1,547 $\mathrm{cm}^{-1}$ were acid amides I and II, affirming that the synthesis proceeded successfully.

\section{Cellular viability evaluation}

The evaluation of cell toxicity from PEG- $b-\mathrm{PBLG}_{50}$ on EC9706 cells was checked in 24-h culturing and the result is revealed in Figure 3B. The PEG- $b-\mathrm{PBLG}_{50}$ showed low cell toxicity even below a concentration as high as $300 \mu \mathrm{g} / \mathrm{mL}$.

\section{Loading capacity of simvastatin in PEG-b-PBLG 50}

Simvastatin could be efficiently loaded through PEG$b$-PBLG $\mathrm{G}_{50}$ at physiological $\mathrm{pH}$ by the hydrophobic interaction. Simvastatin was added to PEG- $b-\mathrm{PBLG}_{50}$ (mass ratio, 1:5) and dialyzed (MWCO, $7 \mathrm{kDa}$ ) against $\mathrm{PB}$ solution $(\mathrm{pH} 7.4,0.01 \mathrm{mmol} / \mathrm{L})$. The dialysis of free simvastatin as a control was also conducted at the same condition in a PB solution. To decide the load of simvastatin in PEG- $b$ PBLG $_{50}$, the quantity of simvastatin was checked by HPLC in the dialysate and deducted from the total quantity of added simvastatin. The load of simvastatin was $41.8 \%$ by calculating, expressed as the mass ratio of loaded simvastatin to the polymeric compound host (Table 1).

\section{Characterization evaluation of simvastatin/polymer compound}

The simvastatin/polymer compound was measured by TEM and the image is revealed in Figure 3A. The simvastatin/ polymer compound showed an orbicular structure and the diameter was $\sim 73 \mathrm{~nm}$ (Table 1 ).

\section{In vitro release of simvastatin from PEG-b-PBLG 50}

The simvastatin release from PEG- $b-\mathrm{PBLG}_{50}$ was measured by dialysis (MWCO, $7 \mathrm{kDa}$ ) under room temperature, with

Table I Molecular weights, polydispersities, TEM, and simvastatinloading capacity of PEG-b-PBLG ${ }_{50}$

\begin{tabular}{llllll}
\hline Sample & $\begin{array}{l}M_{\mathbf{n}}(\mathrm{kDa}) /{ }^{\prime} \mathbf{H} \\
\mathbf{N M R}\end{array}$ & $\begin{array}{l}\boldsymbol{M}_{\mathbf{n}}(\mathrm{kDa}) / \\
\mathbf{G P C}\end{array}$ & PDI & $\begin{array}{l}\text { TEM } \\
(\mathbf{n m})\end{array}$ & $\begin{array}{l}\text { Loading } \\
\text { capacity (\%) }\end{array}$ \\
\hline $\mathrm{P}$ & 28.6 & 18.7 & 1.99 & NA & NA \\
Sim/P & NA & NA & NA & 73 & 41.8 \\
\hline
\end{tabular}

Abbreviations: 'H NMR, 'H-nuclear magnetic resonance; GPC, gel permeation chromatograms; $M_{n}$, number-average molecular weight; NA, not applicable; PDI, polydispersity index; TEM, transmission electron microscopy.
$5 \mathrm{~mL}$ of simvastatin/PEG- $b-\mathrm{PBLG}_{50}$ against a PB solution of $0.02 \mathrm{~mol} / \mathrm{L}$ ( $\mathrm{pH}$ of 7.4). The release curve of simvastatin/ PEG- $b$-PBLG ${ }_{50}$ is depicted in Figure 3C. After $2 \mathrm{~h}, \sim 48.94 \%$ of the simvastatin was released from simvastatin/PEG$b$-PBLG ${ }_{50}$, manifesting the beginning of a burst release of simvastatin. Approximately $67.72 \%$ of the simvastatin was released after 2 days and $\sim 97 \%$ after 4 days, manifesting biphase release profile from simvastatin/PEG- $b-\mathrm{PBLG}_{50}$.

\section{Plasma simvastatin concentration evaluation}

It is shown in Figure 3D. The concentration of simvastatin in the plasma of SD rats following a single subcutaneous injection in Sim group at a dose of $20 \mathrm{mg} / \mathrm{kg}$ rapidly reached $\mathrm{C}_{\max }$ of $163.56 \mathrm{ng} / \mathrm{mL}$ at a $\mathrm{T}_{\max }$ of $2 \mathrm{~h}$, and declined to baseline values within $10 \mathrm{~h}$ of administration. The plasma concentration of SD rats following a single subcutaneous injection in $\mathrm{Sim} / \mathrm{P}$ group at a dose of $20 \mathrm{mg} / \mathrm{kg}$ reached $\mathrm{C}_{\max }$ of $41.25 \mathrm{ng} / \mathrm{mL}$ at a $\mathrm{T}_{\max }$ of $2 \mathrm{~h}$, and declined to baseline values within 4 days of administration. These results showed that the release of simvastatin from Sim/P group was substantially sustained compared to Sim group.

\section{In vivo distribution evaluation of simvastatin/PEG-b-PBLG ${ }_{50}$ compound}

It is depicted in Figure 4. The disintegrations per minute (DPM) of spleen was maximum and then was kidney and heart. However, the DPM of intestine, lung, and liver was minimum. This showed that a part of simvastatin from simvastatin/PEG- $b$-PBLG ${ }_{50}$ compound was swallowed by the phagocyte of spleen, but was not swallowed by the phagocyte of liver, then a part of simvastatin from simvastatin/ PEG- $b$-PBLG ${ }_{50}$ compound accumulated in the kidney, heart,

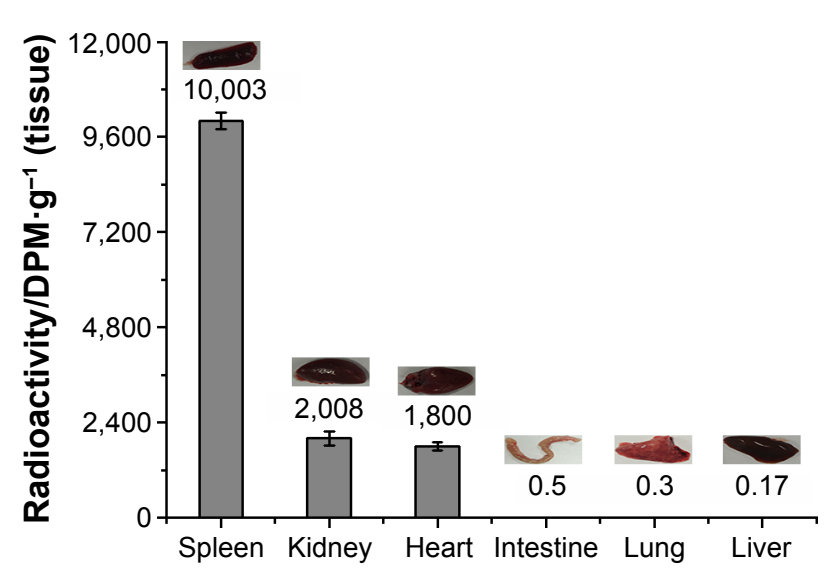

Figure 4 The distribution of simvastatin/polymer compound in rats.

Note: The distribution of simvastatin/PEG-b-PBLG 50 in rats and results expressed as mean \pm standard deviation.

Abbreviation: DPM, disintegrations per minute. 
intestine, and so on. The result showed that simvastatinloaded PEG- $b-$ PBLG $_{50}$ could avoid liver metabolism.

\section{Measurement of SOD activity and MDA content}

As shown in Figure 5A and B, SOD activity in intestinal tissue in $\mathrm{I} / \mathrm{R}$ group rats was less than that in the Sham group $(P<0.01)$. SOD activity in intestinal tissue reached $156.78 \pm 1.24 \mathrm{U}$ in Sham group, whereas SOD activity in intestinal tissue in $\mathrm{I} / \mathrm{R}$ group reached $105.63 \pm 2.78 \mathrm{U}$. Administration of simvastatin increased SOD activity (128.96 $\pm 1.05 \mathrm{U})$ in intestinal tissues, compared with SOD activity in intestinal tissues in the $\mathrm{I} / \mathrm{R}$ group rats $(P<0.01)$. Administration of simvastatin/PEG- $b-\mathrm{PBLG}_{50}$ remarkably increased SOD activity (139.03 $\pm 1.23 \mathrm{U})$, which was remarkably higher than that in the $\mathrm{I} / \mathrm{R}$ group $(P<0.01)$; MDA level in intestinal tissue in $\mathrm{I} / \mathrm{R}$ group rats was greater than in Sham group $(P<0.01)$. MDA content in intestinal tissue reached $0.33 \pm 0.08 \mathrm{nmol}$ in Sham group, whereas MDA content in intestinal tissue in $\mathrm{I} / \mathrm{R}$ group reached $0.71 \pm 0.02 \mathrm{nmol}$. Administration of simvastatin decreased MDA content $(0.51 \pm 0.06 \mathrm{nmol})$ in intestinal tissue, compared with the MDA content in intestinal tissue in the $\mathrm{I} / \mathrm{R}$ group rats $(P<0.01)$. Administration of simvastatin/PEG- $b-\mathrm{PBLG}_{50}$ remarkably decreased MDA content $(0.42 \pm 0.04 \mathrm{nmol})$, which was remarkably lower than that in the $\mathrm{I} / \mathrm{R}$ group $(P<0.01)$.

\section{Measurement of serum IL-4, IL-6, IL-I0, and TNF- $\alpha$ level}

As shown in Figure 5C, IL-4 content in serum in I/R group rats was higher than that in the Sham group $(P<0.01)$. IL-4 content in serum reached $4.19 \pm 0.38 \mathrm{ng}$ in Sham group, whereas IL-4 content in serum in I/R group reached $15.27 \pm 0.71 \mathrm{ng}$. Administration of simvastatin decreased IL-4 content $(11.32 \pm 0.59 \mathrm{ng})$ in serum, compared with the IL-4 content in serum in the $\mathrm{I} / \mathrm{R}$ group rats $(P<0.01)$. Administration of simvastatin/PEG- $b$-PBLG ${ }_{50}$ remarkably decreased IL-4 content ( $8.08 \pm 0.95 \mathrm{ng})$, which was remarkably lower than that in the I/R group $(P<0.01)$; IL-6 content in serum in $\mathrm{I} / \mathrm{R}$ group rats was greater than that in the Sham group $(P<0.01)$. IL-6 level in serum reached $19.36 \pm 1.01 \mathrm{ng}$ in Sham group, whereas IL- 6 content in serum in $\mathrm{I} / \mathrm{R}$ group reached $50.03 \pm 1.22 \mathrm{ng}$. Administration of simvastatin decreased IL-6 content ( $39.85 \pm 0.98 \mathrm{ng})$ in serum, compared with IL-6 content in serum in $\mathrm{I} / \mathrm{R}$ group rats $(P<0.01)$. Administration of simvastatin/PEG- $b$-PBLG ${ }_{50}$ remarkably decreased IL-6 level (28.96 $\pm 1.15 \mathrm{ng}$ ), which was remarkably lower than that in the I/R group $(P<0.01)$; IL-10 content in serum in $\mathrm{I} / \mathrm{R}$ group rats was greater than that in the Sham group $(P<0.01)$. IL-10 content in serum reached $14.65 \pm 1.23 \mathrm{ng}$ in Sham group, whereas IL-10 content in serum in $\mathrm{I} / \mathrm{R}$ group reached $47.53 \pm 2.21 \mathrm{ng}$. Administration of simvastatin increased IL-6 level $(60.03 \pm 2.76 \mathrm{ng})$ in serum, compared with $1 \mathrm{~L}-10$ content in serum in the $\mathrm{I} / \mathrm{R}$ group rats $(P<0.01)$. Administration of simvastatin/PEG- $b$ - PBLG $_{50}$ remarkably increased IL-10 content ( $78.85 \pm 3.01 \mathrm{ng}$ ), which was remarkably greater than that in the $\mathrm{I} / \mathrm{R}$ group $(P<0.01)$; TNF- $\alpha$ content in serum in $\mathrm{I} / \mathrm{R}$ group rats was greater than that in the Sham group $(P<0.01)$. TNF- $\alpha$ content in serum reached $16.74 \pm 1.32 \mathrm{ng}$ in Sham group, whereas TNF- $\alpha$ content in serum in $\mathrm{I} / \mathrm{R}$ group reached $89.23 \pm 2.88 \mathrm{ng}$. Administration of simvastatin decreased TNF- $\alpha$ content $(70.66 \pm 1.78 \mathrm{ng})$ in serum, compared with TNF- $\alpha$ content in serum in $\mathrm{I} / \mathrm{R}$ group rats $(P<0.01)$. Administration of simvastatin/PEG- $b-\mathrm{PBLG}_{50}$ remarkably decreased TNF- $\alpha$ content $(54.15 \pm 1.36 \mathrm{ng})$, which was remarkably lower than that in I/R group $(P<0.01)$.

\section{Measurement of $\mathrm{NO}_{2}^{-} / \mathrm{NO}_{3}{ }^{-}$content and $\mathrm{dry} /$ wet intestine ratios}

As shown in Figure $5 \mathrm{D}$ and $\mathrm{E}, \mathrm{NO}_{2}{ }^{-} \mathrm{NO}_{3}{ }^{-}$content in serum in $\mathrm{I} / \mathrm{R}$ group rats was lower than that in the Sham group $(P<0.01)$. $\mathrm{NO}_{2}-\mathrm{NO}_{3}{ }^{-}$content in serum reached $24.27 \pm 1.08 \mu \mathrm{mol}$ in Sham group, whereas $\mathrm{NO}_{2}^{-} / \mathrm{NO}_{3}^{-}$content in serum in $\mathrm{I} / \mathrm{R}$ group reached $7.8 \pm 1.11 \mu \mathrm{mol}$. Administration of simvastatin increased $\mathrm{NO}_{2}{ }^{-} / \mathrm{NO}_{3}{ }^{-}$content $(9.1 \pm 0.87 \mu \mathrm{mol})$ in serum, compared with $\mathrm{NO}_{2}{ }^{-} / \mathrm{NO}_{3}{ }^{-}$content in serum in $\mathrm{I} / \mathrm{R}$ group rats $(P<0.01)$. Administration of simvastatin/PEG- $b-\mathrm{PBLG}_{50}$ remarkably increased $\mathrm{NO}_{2}{ }^{-} / \mathrm{NO}_{3}{ }^{-}$content $(12.3 \pm 0.65 \mu \mathrm{mol})$, which was remarkably greater than that in the $\mathrm{I} / \mathrm{R}$ group $(P<0.01)$; the dry/wet $(\mathrm{D} / \mathrm{W})$ intestine ratios in $\mathrm{I} / \mathrm{R}$ groups rats were lower than those in Sham group $(P<0.01)$. The $\mathrm{D} / \mathrm{W}$ intestine ratios reached $3.08 \pm 0.06$ in Sham group, whereas the $\mathrm{D} / \mathrm{W}$ intestine ratios in $\mathrm{I} / \mathrm{R}$ groups reached $6.25 \pm 0.09$. Administration of simvastatin increased the $\mathrm{D} / \mathrm{W}$ intestine ratios $(5.17 \pm 0.08)$ compared with the $\mathrm{D} / \mathrm{W}$ intestine ratios in $\mathrm{I} / \mathrm{R}$ group rats $(P<0.01)$, whereas administration of simvastatin/PEG- $b$ - PBLG $_{50}$ remarkably increased the D/W intestine ratios $(4.46 \pm 0.10)$, which were remarkably higher than those in $\mathrm{I} / \mathrm{R}$ group $(P<0.01)$.

\section{ROS analysis}

Fluorescence microscopy images of intestine parts are shown in Figure 6. CM- $\mathrm{H}_{2}$ DCFDA-positive cells were absent in intestinal tissue parts from Sham group. I/R group augmented mitochondrial ROS production, as affirmed through significant epithelial cell staining (CM-H2DCFDA fluorescence) of 
A

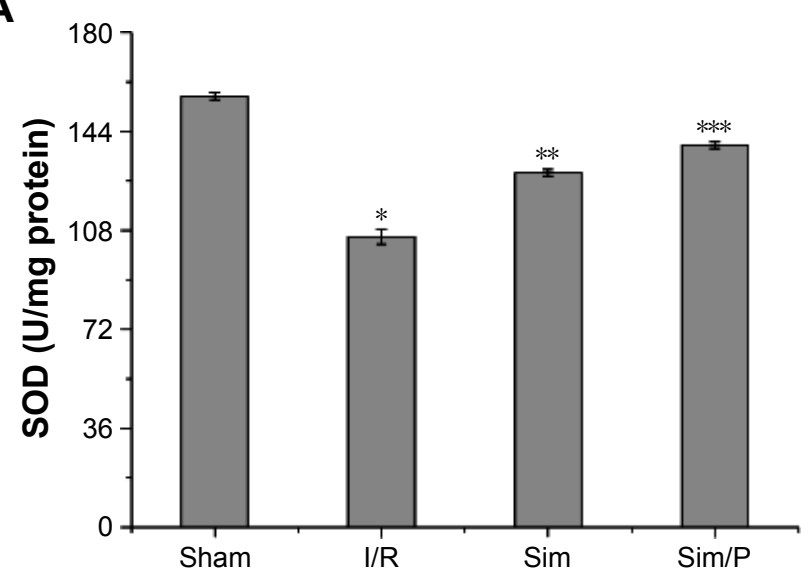

C

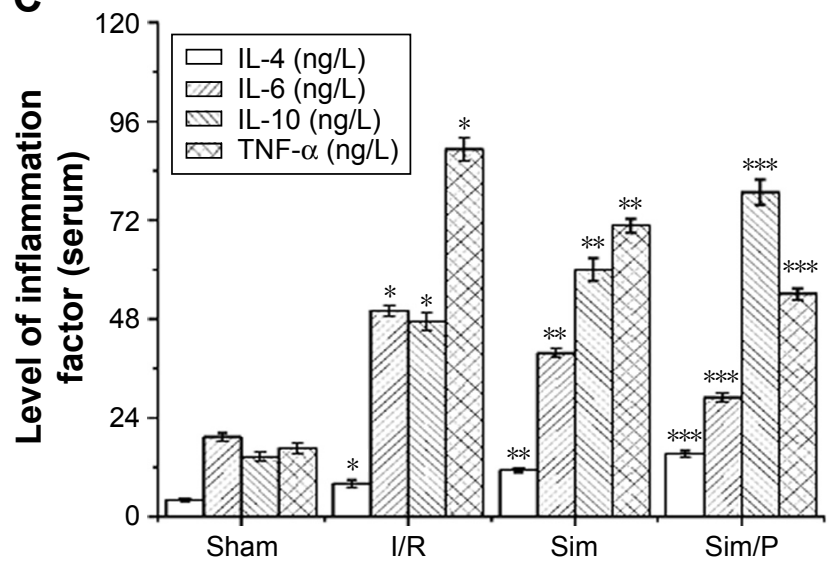

B

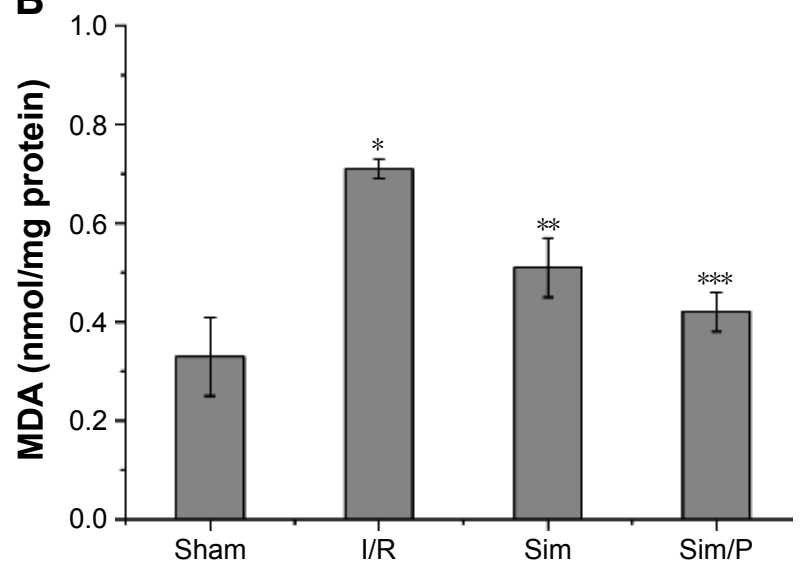

D

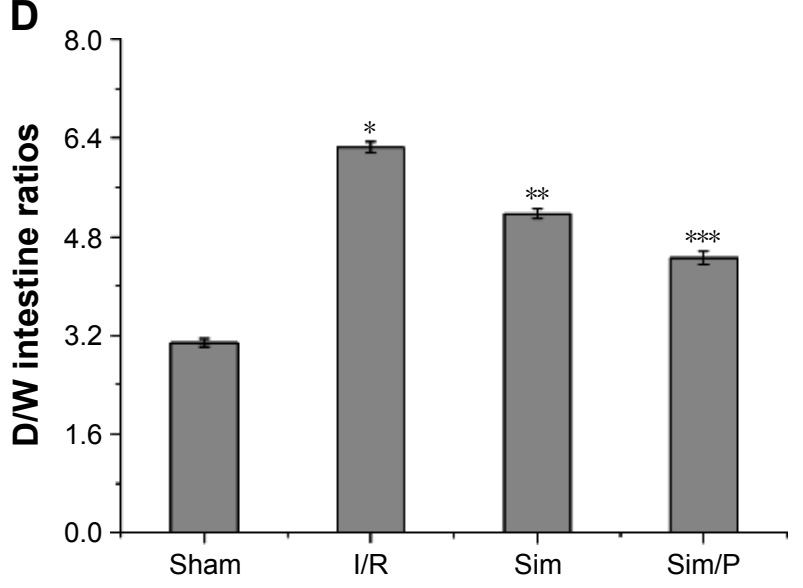

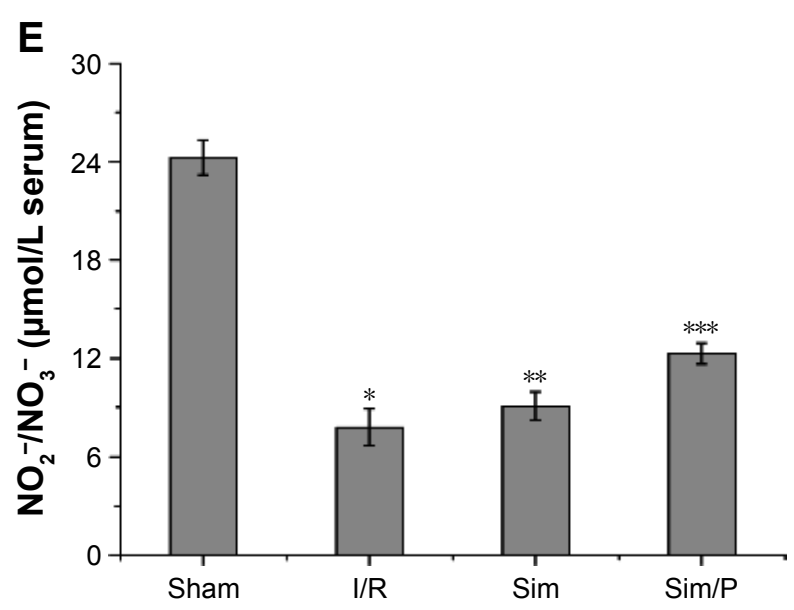

Figure 5 (A) SOD activity; (B) MDA level; (C) Level of IL-4, IL-6, IL-I0, and TNF- $\alpha$; (D) D/W intestine ratios; (E) Level of serum $\mathrm{NO}_{2}^{-} / \mathrm{NO}_{3}^{-}$.

Notes: The intestinal tissues and serum of Sham, I/R, Sim, and Sim/P group rats were collected I h after reperfusion and the level of SOD, MDA, IL-4, IL-6, IL-I0, TNF- $\alpha$, $\mathrm{D} / \mathrm{W}$ intestine ratios, and $\mathrm{NO}_{2}{ }^{-} / \mathrm{NO}_{3}{ }^{-}$measured. Results are expressed as mean \pm standard deviation. (A) A significant decrease from Sham group is denoted by $* P<0.0 \mathrm{I}$, an increase from I/R group is denoted by $* * P<0.01$, and a significant increase from I/R group is denoted by $* * * P<0.01$. (B) A significant increase from Sham group is denoted by $* P<0.01$, a decrease from I/R group is denoted by $* * P<0.01$, and a significant decrease from I/R group is denoted by $* * * P<0.01$. (C) $A$ significant increase from Sham group is denoted by $* P<0.0 I$, an increase from I/R group is denoted by $* * P<0.0 I$, and a significant increase from I/R group is denoted by $* * * P<0.0 \mathrm{I}$ (IL-4 and IL-I0); a significant increase from Sham group is denoted by $* P<0.0 \mathrm{I}$, a decrease from I/R group is denoted by $* * P<0.0 \mathrm{I}$, and a significant decrease from I/R group is denoted by $* * * P<0.0 \mathrm{I}$ (IL-6 and TNF- $\alpha$ ). (D) A significant increase from Sham group is denoted by $* P<0.01$, a decrease from I/R group is denoted by $* * P<0.0 \mathrm{I}$, and a significant decrease from I/R group is denoted by $* * * P<0.01$. (E) A significant decrease from Sham group is denoted by $* P<0.01$, an increase from I/R group is denoted by $* * P<0.0 \mathrm{I}$, and a significant increase from I/R group is denoted by $* * * P<0.01$.

Abbreviations: D/W, dry/wet; I/R, ischemia/reperfusion; IL-I0, interleukin-I0; MDA, methane dicarboxylic aldehyde; SOD, superoxide dismutase; TNF- $\alpha$, tumor necrosis factor- $\alpha$; Sim, simvastatin; Sim/P, simvastatin/PEG-b-PBLG ${ }_{50}$. 


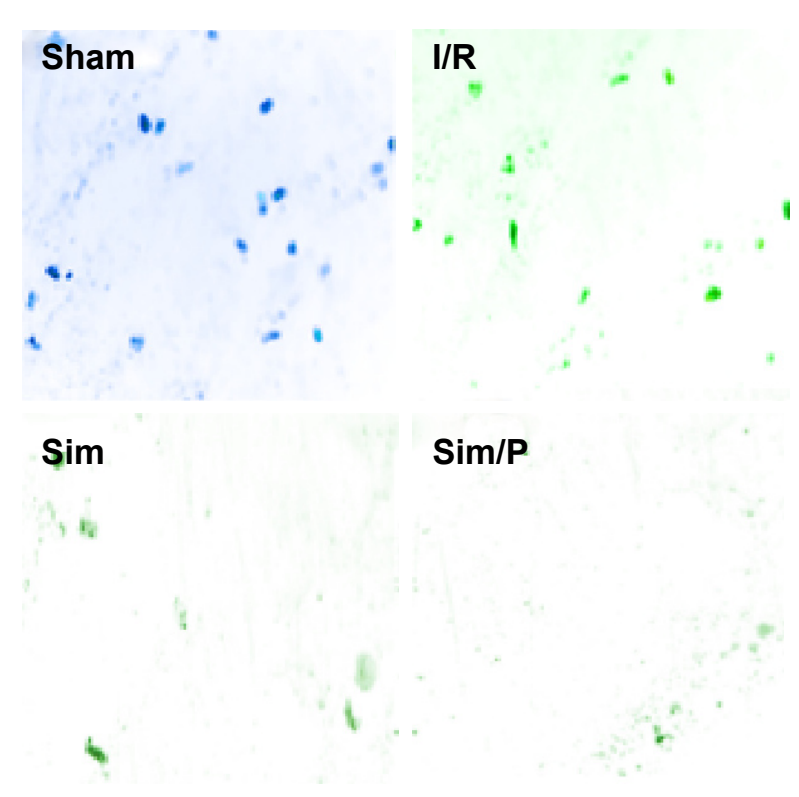

Figure 6 Expression of ROS in different groups of rats.

Notes: The intestinal tissues of Sham, I/R, Sim, and Sim/P group rats were collected $\mathrm{I} \mathrm{h}$ after reperfusion and the expression of ROS measured. ROS expression in I/R group rats was higher than that in the Sham group; ROS expression in Sim group rats was less than that in the I/R group; ROS expression in Sim/P group rats was significantly less than that in the I/R group.

Abbreviations: I/R, ischemia/reperfusion; ROS, reactive oxygen species; Sim, simvastatin; Sim/P, simvastatin/PEG-b-PBLG ${ }_{50}$.

intestine tissue parts. Sim/P group significantly reduced ROS production, compared with production of ROS in I/R group.

\section{Western blot evaluation}

eNOS, p47phox, p38MAPK, BMP4, and COX-2 expressions in intestinal tissues were checked by Western blot following the previously published method. ${ }^{21,38-40}$ The qualitative and quantitative outcomes are evaluated in Figure 7. The eNOS expressions in intestinal tissue in $\mathrm{I} / \mathrm{R}$ group were greater than those in Sham group $(P<0.01)$. Administration of simvastatin upregulated the eNOS expressions in intestinal tissue, compared with eNOS expressions by $\mathrm{I} / \mathrm{R}$ group $(P<0.01)$. Administration of simvastatin/PEG- $b-\mathrm{PBLG}_{50}$ remarkably upregulated eNOS expressions, compared with those in $\mathrm{I} / \mathrm{R}$ group $(P<0.01)$.

The p47phox, p38MAPK, BMP4, and COX-2 expressions in intestinal tissue in $\mathrm{I} / \mathrm{R}$ group were greater than those in Sham group $(P<0.01)$. Administration of simvastatin downregulated p47phox, p38MAPK, BMP4, and COX-2 expressions in intestinal tissue, compared with p47phox, p38MAPK, BMP4, and COX-2 expressions in $\mathrm{I} / \mathrm{R}$ groups $(P<0.01)$. Administration of simvastatin/ PEG- $b-$ PBLG $_{50}$ remarkably downregulated $\mathrm{p} 47$ phox, p38MAPK, BMP4, and COX-2 expressions, compared with those in $\mathrm{I} / \mathrm{R}$ group $(P<0.01)$.

\section{Immunohistochemical analysis}

As shown in Figure 8, expressions of COX-2, BMP4, and p38MAPK in intestinal tissues that were induced by $I / R$ are greater than those in Sham group. Administration of simvastatin downregulated COX-2, BMP4, and p38MAPK expressions in intestinal tissue, compared with COX-2, BMP4, and $\mathrm{p} 38 \mathrm{MAPK}$ expressions in intestinal tissue by induced I/R group, whereas administration of simvastatin/PEG- $b-\mathrm{PBLG}_{50}$ downregulated COX-2, BMP4, and p38MAPK expressions, which were remarkably lower than in the I/R group.

\section{Discussion}

This is the first research to reveal that simvastatin and simvastatin/PEG- $b$-PBLG ${ }_{50}$ pretreatment can both weaken intestine injury induced by intestinal $\mathrm{I} / \mathrm{R}$. We discovered that intestinal inflammatory reaction is remarkably mitigated after simvastatin and simvastatin/PEG- $b-$ PBLG $_{50}$ preconditioning. The protective action is partially downregulated with BMP4 and $\mathrm{COX}-2$, manifesting that the underlying mechanisms are associated with either BMP4 and COX-2-dependent or -independent pathways.

The intestinal mucosal injury is a major factor contributing to the pernicious complications of intestinal II/RI. ${ }^{44}$ It is a well-known phenomenon that ROS-induced lipid peroxidation, proinflammatory and anti-inflammatory imbalance, and disorder of nitroso-redox balance lead to intestinal injury. ${ }^{12,22,45}$ Previous documents have also demonstrated that powerful oxidative stress starting in the epithelium upon recovery of blood cell circulations is a primary reason of necrosis of the intestinal epithelium on I/R-induced injury. ${ }^{46}$ In the present study, we demonstrate that simvastatin and simvastatin/PEG- $b$-PBLG ${ }_{50}$ pretreatment ameliorate oxidative stress damage, bate inflammatory response, and restore nitroso-redox balance (Figures 5, 6, and 7A).

In the study, we find that on II/RI rats, the protein contents and expression of BMP4 are augmented, and then p38MAPK and oxidative stress are activated, leading to upregulation of COX-2 protein levels and expression, where the pathway contributes to augmentation of II/RI. Simvastatin and simvastatin/PEG- $b$-PBLG ${ }_{50}$ interestingly reverse the activation of the above pathway (Scheme 1). This also shows that BMP4 can enhance NADPH oxidase to promote NADPH oxidase subtype (including $\mathrm{p} 47 \mathrm{phox}$ ) expression, resulting in COX-2 expression upregulation through p38MAPKdependent mechanism in our research. In our study, we found that simvastatin and simvastatin/PEG- $b-\mathrm{PBLG}_{50}$ attenuate BMP4, COX-2, p47phox, p38MAPK, and ROS 

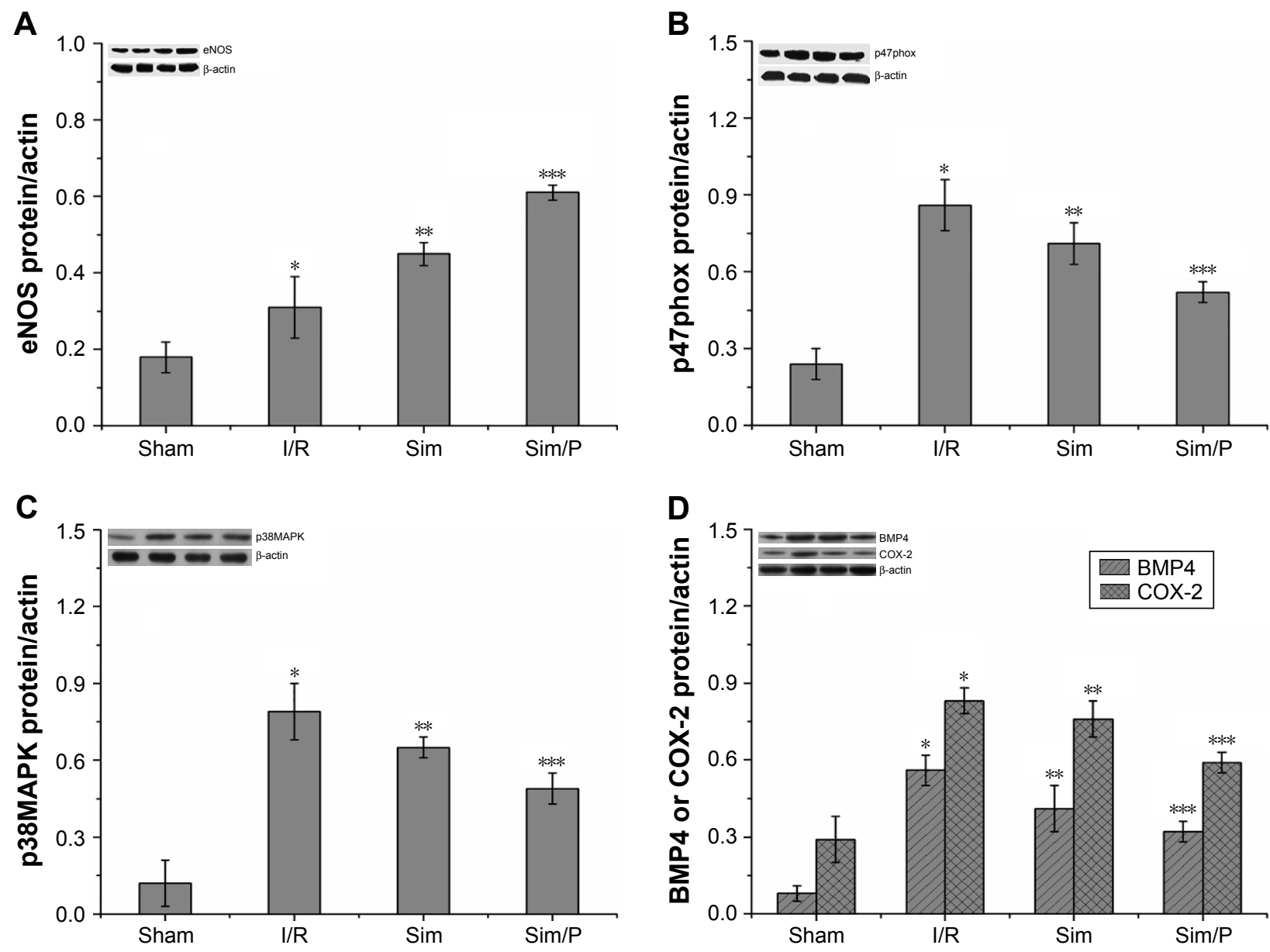

Figure 7 Expression of eNOS (A), p47phox (B), p38MAPK (C), BMP4, and COX-2 (D) in different groups of rats.

Notes: The intestinal tissues of Sham, I/R, Sim, and Sim/P group rats were collected I h after reperfusion and the expressions of eNOS, p47phox, p38MAPK, BMP4, and COX-2 measured. Results are expressed as mean \pm standard deviation. (A) A significant increase from Sham group is denoted by $* P<0.0$ I, an increase from I/R group is denoted by $* * P<0.01$, and a significant increase from I/R group is denoted by $* * P<0.01$. (B) A significant increase from Sham group is denoted by $* P<0.01$, a decrease from $I / R$ group is denoted by $* * P<0.01$, and a significant decrease from I/R group is denoted by $* * * P<0.01$. (C) A significant increase from Sham group is denoted by $* P<0.01$, a decrease from I/R group is denoted by $* * P<0.01$, and a significant decrease from I/R group is denoted by $* * * P<0.01$. (D) A significant increase from Sham group is denoted by $* P<0.01$, a decrease from I/R group is denoted by $* * P<0.01$, and a significant decrease from I/R group is denoted by $* * * P<0.01$.

Abbreviations: BMP4, bone morphogenetic protein 4; COX-2, cyclooxygenase-2; eNOS, endothelial nitric oxide synthase; I/R, ischemia/reperfusion; p38MAPK, p38 mitogen-activated protein kinase; p47phox, protein 47 kDa phagocyte oxidase; Sim, simvastatin; Sim/P, simvastatin/PEG-b-PBLG ${ }_{50}$.

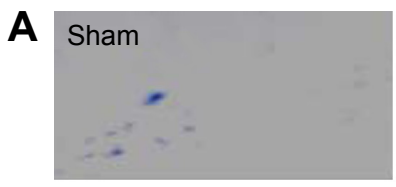

B Sham

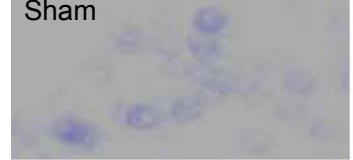

C

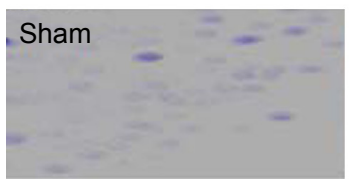

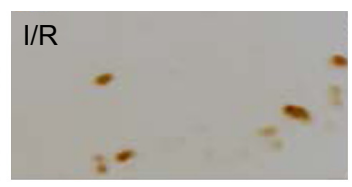
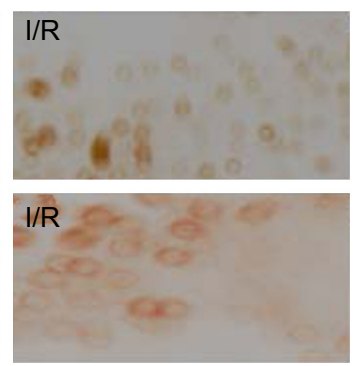
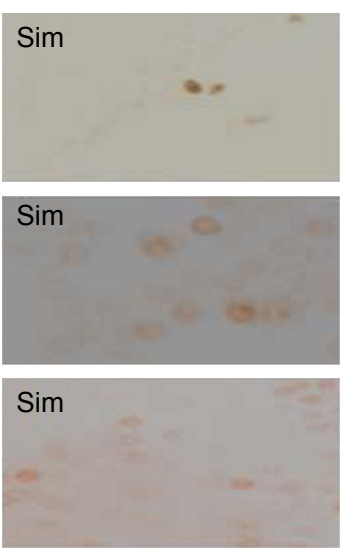

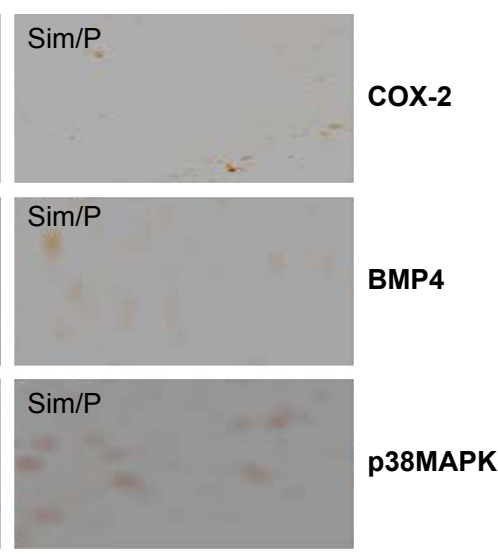

Figure 8 Expression of COX-2 (A), BMP4 (B), and p38MAPK (C) in different groups of rats.

Notes: The intestinal tissues of Sham, I/R, Sim, and Sim/P group rats were collected I h after reperfusion and the expression of ROS measured. COX-2, BMP4, and P38MAPK expressions in I/R group rats were higher than those in Sham group; COX-2, BMP4, and p38MAPK expressions in Sim group rats were less than those in I/R group; COX-2, BMP4, and P38MAPK expressions in Sim/P group rats were significantly less than those in I/R group.

Abbreviations: BMP4, bone morphogenetic protein 4; COX-2, cyclooxygenase-2; I/R, ischemia/reperfusion; p38MAPK, p38 mitogen-activated protein kinase; Sim, simvastatin; Sim/P, simvastatin/PEG- $b-$ PBLG $_{50}$. 
Simvastatin/simvastatin nanoparticle

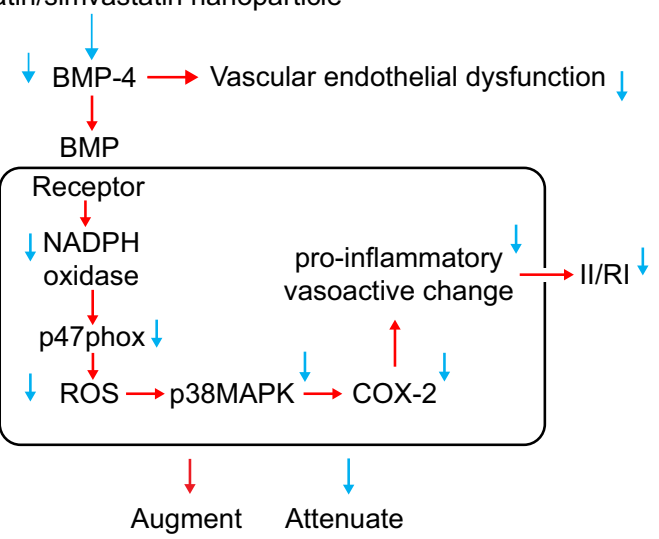

Scheme I Graphical representation of the ameliorative effect of simvastatin/PEGb-PBLG 50 on II/RI.

Notes: Red arrow represents damage process; blue arrow represents mitigation process of damage.

Abbreviations: BMP4, bone morphogenetic protein; p47phox, protein $47 \mathrm{kDa}$ phagocyte oxidase; PEG-b-PBLG ${ }_{50}$, poly(ethylene glycol)-b-poly(gamma-benzyl L-glutamate); ROS, reactive oxygen species; p38MAPK, p38 mitogen-activated protein kinase; COX-2, Cyclooxygenases-2; II/RI, intestinal ischemia/reperfusion injury.

expression. All of the above experimental results attest that BMP4/ROS/p38MAPK/COX-2 pathway is involved in II/ RI. These results are in agreement with other documents. ${ }^{21}$ To sum up, our present research reveals that simvastatin and simvastatin/PEG- $b$ - PBLG $_{50}$ preconditioning can provide intestine protection after II/RI through downregulating BMP4/COX-2 pathway, whereas simvastatin/PEG- $b-$ PBLG $_{50}$ significantly improves the effect.

In addition, there are some limitations in our research. In our tests, the HE staining is not measured owing to the limited number of mice. On the other hand, we only found the association between simvastatin and simvastatin/ PEG- $b$-PBLG ${ }_{50}$ and the BMP4/ROS/p38MAPK/COX-2 pathway. The exact mechanism of how simvastatin and simvastatin/PEG- $b$-PBLG regulate the above pathway needs to be further explored.

\section{Conclusion}

The synthesized PEG- $b$ - PBLG $_{50}$ can evidently enhance the bioactivity of simvastatin, and the distribution experiment shows that simvastatin/PEG- $b-\mathrm{PBLG}_{50}$ can escape liver phagocytosis to improve the circulation time of simvastatin in vivo. The observational protective effect can be due to the antioxidative stress, anti-inflammatory properties, and the regulation of BMP4/COX-2 pathway by simvastatin/PEG- $b$-PBLG ${ }_{50}$ in rats as compared to free simvastatin. Further detailed research is required to probe the underlying mechanisms of simvastatin/PEG- $b-\mathrm{PBLG}_{50}$ on II/RI in rats.

\section{Acknowledgment}

This study was financially supported by the Department of Education, Zhejiang Government under Key Research Program.

\section{Author contributions}

All authors contributed toward data analysis, drafting and critically revising the paper, gave final approval of the version to be published, and agree to be accountable for all aspects of the work.

\section{Disclosure}

The authors report no conflicts of interest in this work.

\section{References}

1. Sukhotnik I, Nissimov N, Ben Shahar Y, et al. Fenofibrate reduces intestinal damage and improves intestinal recovery following intestinal ischemia-reperfusion injury in a rat. Pediatr Surg Int. 2016;32(12): 1193-1200.

2. Deitch EA. Multiple organ failure. Pathophysiology and potential future therapy. Ann Surg. 1992;216(2):117-134.

3. Cámara CR, Guzmán FJ, Barrera EA, et al. Ketamine anesthesia reduces intestinal ischemia/reperfusion injury in rats. World $J$ Gastroenterol. 2008;14(33):5192-5196.

4. Chang RW, Chang JB, Longo WE. Update in management of mesenteric ischemia. World J Gastroenterol. 2006;12(20):3243-3247.

5. Slijper N, Sukhotnik I, Chemodanov E, et al. Effect of simvastatin on intestinal recovery following gut ischemia-reperfusion injury in a rat. Pediatr Surg Int. 2010;26(1):105-110.

6. Moore RM, Muir WW, Granger DN. Mechanisms of gastrointestinal ischemia-reperfusion injury and potential therapeutic interventions: a review and its implications in the horse. J Vet Intern Med. 1995;9(3): $115-132$.

7. Khanna A, Rossman J, Caty MG, Fung HL. Beneficial effects of intraluminal nitroglycerin in intestinal ischemia-reperfusion injury in rats. J Surg Res. 2003;114(1):15-24.

8. Wang G, Yao J, Li Z, et al. miR-34a-5p inhibition alleviates intestinal ischemia/reperfusion-induced reactive oxygen species accumulation and apoptosis via activation of SIRT1 signaling. Antioxid Redox Signal. 2016;24(17):961-973.

9. Nakagiri A, Sunamoto M, Murakami M. NADPH oxidase is involved in ischaemia/reperfusion-induced damage in rat gastric mucosa via ROS production-role of NADPH oxidase in rat stomachs. Inflammopharmacology. 2007;15(6):278-281.

10. Babior BM. NADPH oxidase: an update. Blood. 1999;93(5): 1464-1476.

11. Luo L, Li YC, Dai XZ, et al. Effects of proanthocyanidins on intestinal motility disturbance following intestinal ischemia/reperfusion. $J$ Invest Surg. 2016;29(6):335-342.

12. Farmer DG, Shen XD, Amersi F, et al. CD62 blockade with P-Selectin glycoprotein ligand-immunoglobulin fusion protein reduces ischemiareperfusion injury after rat intestinal transplantation. Transplantation. 2005;79(1):44-51.

13. Shu X, Zhang J, Wang Q, Xu Z, Yu T. Glutamine decreases intestinal mucosal injury in a rat model of intestinal ischemia-reperfusion by downregulating HMGB1 and inflammatory cytokine expression. Exp Ther Med. 2016;12(3):1367-1372.

14. Chen D, Zhao M, Mundy GR. Bone morphogenetic proteins. Growth Factors. 2004;22(4):233-241.

15. Upton PD, Long L, Trembath RC, Morrell NW. Functional characterization of bone morphogenetic protein binding sites and Smad1/5 activation in human vascular cells. Mol Pharmacol. 2008;73(2):539-552. 
16. Lee J, Stavropoulos A, Susin C, Wikesjö UME. Periodontal regeneration: focus on growth and differentiation factors. Dental Clin North Am. 2010;54(1):93-111.

17. Vukicevic S, Paralkar VM, Cunningham NS, Gutkind JS, Reddi AH. Autoradiographic localization of osteogenin binding sites in cartilage and bone during rat embryonic development. Dev Biol. 1990;140(1):209-214.

18. Haidar ZS, Hamdy RC, Tabrizian M. Delivery of recombinant bone morphogenetic proteins for bone regeneration and repair-part A: current challenges in BMP delivery. Biotechnol Lett. 2009;31(12):1817-1824.

19. Gu GL, Yang QY, Zeng RL, Xu XL. The association between BMP4 gene polymorphism and its serum level with the incidence of LVH in hypertensive patients. J Transl Med. 2015;13:14.

20. Csiszar A, Labinskyy N, Jo H, Ballabh P, Ungvari Z. Differential proinflammatory and prooxidant effects of bone morphogenetic protein- 4 in coronary and pulmonary arterial endothelial cells. Am J Physiol Heart Circ Physiol. 2008;295(2):H569-H577.

21. Xiao L, Dong JH, Jin S, et al. Hydrogen sulfide improves endothelial dysfunction via downregulating BMP4/COX-2 pathway in rats with hypertension. Oxid Med Cell Longev. 2016;2016:8128957.

22. Hajipour B, Somi MH, Saberifar F, et al. Simvastatin attenuates intestinal ischemia/reperfusion induced injury in rat. Folia Morphol (Warsz). 2009;68(3):156-162.

23. Slijper N, Sukhotnik I, Chemodanov E, et al. Effect of simvastatin on intestinal recovery following gut ischemia-reperfusion injury in a rat. Pediatr Surg Int. 2010;26(1):105-110.

24. Pirat A, Zeyneloglu P, Aldemir D, et al. Pretreatment with simvastatin reduces lung injury related to intestinal ischemia-reperfusion in rats. Anesth Analg. 2006;102(1):225-232.

25. Yasugi K, Nagasaki Y, Kato M, Kataoka K. Preparation and characterization of polymer micelles from poly(ethylene glycol)-poly(D,Llactide) block copolymers as potential drug carrier. J Control Release. 1999;62(1-2):89-100.

26. Kreuter J. Nanoparticles and microparticles for drug and vaccine delivery. J Anat. 1996;189:503-505.

27. Sharma D, Chelvi TP, Kaur J, et al. Novel Taxol formulation: polyvinylpyrrolidone nanoparticle-encapsulated taxol for drug delivery in cancer therapy. Oncol Res. 1996;8(7-8):281-286.

28. Hideharu M, Mizuki I, Satoko I, Takeshi E. Ring-opening polymerization of $\gamma$-benzyl-1-glutamate- $N$-carboxyanhydride in ionic liquids. Polymer. 2007;48:5867-5877.

29. Tong F, Tang X, Li X, Xia W, Liu D. The effect of insulin-loaded linear poly(ethylene glycol)-brush-like poly(l-lysine) block copolymer on renal ischemia/reperfusion-induced lung injury through downregulating hypoxia-inducible factor. Int J Nanomedicine. 2016; 11:1717-1730.

30. Zhang Z, Bu H, Gao Z, Huang Y, Gao F, Li Y. The characteristics and mechanism of simvastatin loaded lipid nanoparticles to increase oral bioavailability in rats. Int J Pharm. 2010;394(1-2):147-153.

31. Li S, Jiang WQ, Wang AX, Guan ZZ, Zhang L, Pan SR. Releasing characterization, pharmacokinetics and distribution of PEG-PBLG copolymer micells in vitro and in vivo. Chinese Pharm J. 2005;40(9): 699-702.

32. Shi H, Li R, Qiang J, Li Y, Wang L, Sun R. Computed tomography perfusion imaging detection of microcirculatory dysfunction in small intestinal ischemia-reperfusion injury in a porcine model. PLoS One. 2016;11(7):e0160102.
33. Bentur OS, Chernichovski T, Ingbir M, Weinstein T, Schwartz IF. Dimethyl sulfoxide attenuates nitric oxide generation via modulation of cationic amino acid transporter-1 in human umbilical vein endothelial cells. Cryobiology. 2016;73(2):226-231.

34. Kristiansen KA, Jensen PE, Møller IM, Schulz A. Monitoring reactive oxygen species formation and localisation in living cells by use of the fluorescent probe CM-H(2)DCFDA and confocal laser microscopy. Physiol Plant. 2009;136(4):369-383.

35. Oparka M, Walczak J, Malinska D, et al. Quantifying ROS levels using CM-H2DCFDA and HyPer. Methods. 2016;109:3-11.

36. Tan X, Zhang L, Jiang Y, et al. Postconditioning ameliorates mitochondrial DNA damage and deletion after renal ischemic injury. Nephrol Dial Transplant. 2013;28(11):2754-2765.

37. Doi K, Suzuki Y, Nakao A, Fujita T, Noiri E. Radical scavenger edaravone developed for clinical use ameliorates ischemia/reperfusion injury in rat kidney. Kidney Int. 2004;65(5):1714-1723.

38. Naito Y, Katada K, Takagi T, et al. Rosuvastatin reduces rat intestinal ischemia-reperfusion injury associated with the preservation of endothelial nitric oxide synthase protein. World J Gastroenterol. 2006; 12(13):2024-2030.

39. Li X, Schwacha MG, Chaudry IH, Choudhry MA. Heme oxygenase-1 protects against neutrophil-mediated intestinal damage by down-regulation of neutrophil p47phox and p67phox activity and O2- production in a two-hit model of alcohol intoxication and burn injury. J Immunol. 2008;180(10):6933-6940.

40. Zhang CP, Li XC, Tang RX, Li XY, Zheng KY, Zeng LY. Effects of p38MAPK inhibitor on the occurrence of acute GVHD and intestine damage after allogeneic hematopoietic stem cell transplantation in mice. Zhonghua Xue Ye Xue Za Zhi. 2013;34(8):673-678.

41. Tarantino U, Scimeca M, Piccirilli E, et al. Sarcopenia: a histological and immunohistochemical study on age-related muscle impairment. Aging Clin Exp Res. 2015;27(Suppl 1):S51-S60.

42. Ouyang J, Zhang ZH, Zhou YX, et al. Up-regulation of tight-junction proteins by $\mathrm{p} 38$ mitogen-activated protein Kinase/p53 inhibition leads to a reduction of injury to the intestinal mucosal barrier in severe acute pancreatitis. Pancreas. 2016;45(8):1136-1144.

43. Han YM, Park JM, Cha JY, Jeong M, Go EJ, Hahm KB. Endogenous conversion of $\omega-6$ to $\omega-3$ polyunsaturated fatty acids in fat- 1 mice attenuated intestinal polyposis by either inhibiting $\mathrm{COX}-2 / \beta$-catenin signaling or activating 15-PGDH/IL-18. Int J Cancer. 2016;138(9): 2247-2256.

44. Zu G, Yao J, Ji A, et al. Nurr1 promotes intestinal regeneration after ischemia/reperfusion injury by inhibiting the expression of p21 (Wafl/ Cip1). J Mol Med (Berl). 2017;95(1):83-95.

45. Chen CF, Leu FJ, Chen HI, Wang D, Chou SJ. Ischemia/reperfusioninduced low reactivity of the rat superior mesenteric vascular bed is associated with expression of nitric oxide synthases. Transplant Proc. 2006;38(7):2216-2220.

46. Gordeeva AE, Temnov AA, Charnagalov AA, Sharapov MG, Fesenko EE, Novoselov VI. Protective effect of peroxiredoxin 6 in ischemia/reperfusion-induced damage of small intestine. Dig Dis Sci. 2015;60(12):3610-3619.
International Journal of Nanomedicine

\section{Publish your work in this journal}

The International Journal of Nanomedicine is an international, peerreviewed journal focusing on the application of nanotechnology in diagnostics, therapeutics, and drug delivery systems throughout the biomedical field. This journal is indexed on PubMed Central, MedLine, CAS, SciSearch ${ }^{\circledR}$, Current Contents ${ }^{\circledR} /$ Clinical Medicine,
Dovepress

Journal Citation Reports/Science Edition, EMBase, Scopus and the Elsevier Bibliographic databases. The manuscript management system is completely online and includes a very quick and fair peer-review system, which is all easy to use. Visit http://www.dovepress.com/ testimonials.php to read real quotes from published authors. 